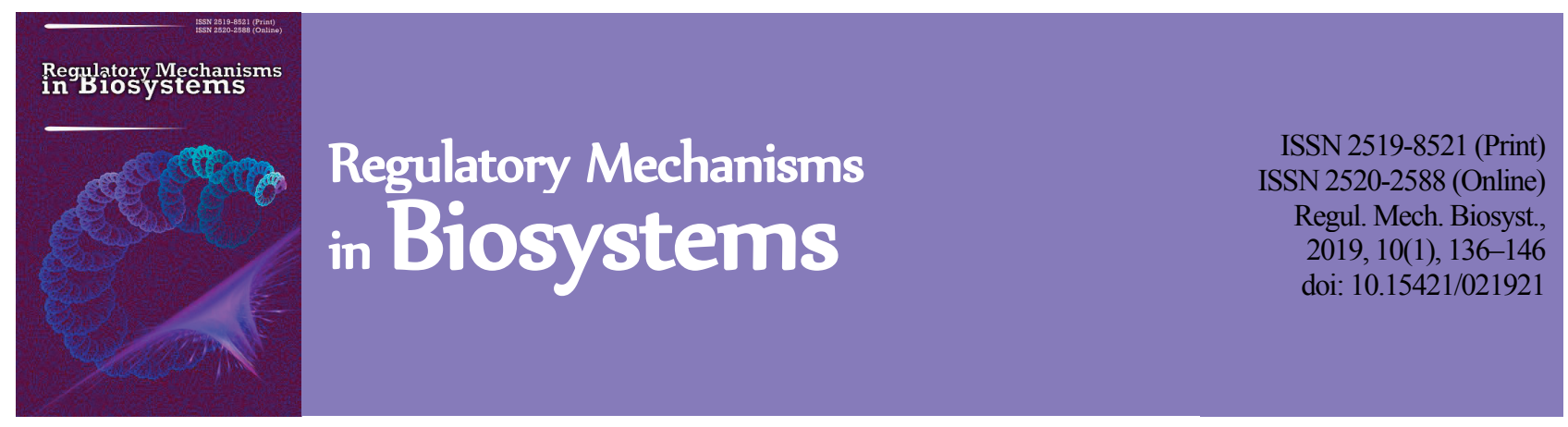

\title{
Ontogenesis of the genets and ramets of some European species of the genus Sparganium subgenus Xanthosparganium
}

\author{
E. A. Belyakov****, A. G. Lapirov* \\ *Papanin Institute for Biology of Inland Waters, Borok, Russia \\ **Cherepovets State University, Cherepovets, Russia
}

Article info

Received 03.01.2019

Received in revised form 11.02 .2019

Accepted 13.02.2019

Papanin Institute for Biology of Inland Waters, RAS, Borok, Nekouz district, Yaroslavl Region, 152742, Russia.

Tel.: 48-547-24-0-42. E-mail: eugenybeliakov@yandex.ru

Cherepovets State University, Lunacharsky ave., 5 , Cherepovets, 162600, Russia.
Belyakov, E. A., \& Lapirov, A. G. (2019). Ontogenesis of the genets and ramets of some European species of the genus Sparganium subgenus Xanthosparganium. Regulatory Mechanisms in Biosystems, 10(1), 136-146. doi:10.15421/021921

Representatives of the Sparganium L. genus belong to an ecological group of short grass helophytes which live in the shoreline area of different water bodies. Despite the fact that most representatives of the genus exhibit notable polymorphism (depending on the level regime of a water body, they can form various ecological forms), characteristic of all of them is presence of only one living form - vegetative mobile clear polycentric long-rhizomatous pseudoannual polycarpic plant with racemose root system. The objective of the article was to study the ontogenesis of genets and ramets on the example of representatives of the Xanthosparganium subgenus (S. emersum Rehm., S. glomeratum (Laest. ex Beurl.) Neum., S. gramineum Georgi and S. natans L.). The research was conducted using the ontogenetic approach. In the study, we analyzed ontogenesis of genet (from generative diaspore) and ontogenesis of ramets (from vegetative diaspores - tuber-like structures and axillary buds of vegetative-generative monocarpic and vegetative rosette shoots). We demonstrated that ontogenesis of genets and ramets (on the basis of tuber-like structures) in laboratory conditions is abrupt. It was found that the model species of Sparganium are characteristic in combining of incomplete and special ontogenesis, which is related to the omission of phases of the post-generative period. Such peculiarity is conditioned by increase in tempi of ontogenetic development. On the basis of specific ontogenesis, a variant of shortened ontogenesis is possible, during which the virginile ontogenetic condition is omitted. This feature could be characterized as dynamic polyvariance of ontogenesis, whereas bud initiation and development of shoots throughout the vegetative season, characterized as heterochrony, has been formed over the process of natural selection. Heterochrony (on the basis of iterative branching without periods of rest) includes a property of formation of vegetative-generative shoots which develop on the basis of sylleptic shoots of subsequent orders of branching. The main course of ontogenesis in natural conditions corresponds to D-type which occurs in order of generations of individuals of vegetative origin.

Keywords: bur-reed; vegetative and generative reproduction; polyvariance of ontogenesis; age state; ramet; adaptation.

\section{Introduction}

One of the most important directions in research on life strategy of species is study of a broad range of question in plant biology, where one of leading aspects is ontogenesis (Zhukova \& Glotov, 2001; Savinykh \& Cheryomushkina, 2015; Zhukova et al., 2016; Logofet et al., 2017; Lapirov et al., 2018). Knowledge on specifics and polyvariance of individual development of plants contributes to integrated understanding of morphological adaptations of plants. These data are especially valuable in study of rare, endangered and valuable medicinal species of plants. Therefore, a large number of studies is focused on ontogenesis of Lobelia dortmanna L., a rare, slowly growing relic aquatic plant (Szmeja, 1987a, 1987b, 1994; Lapirov et al., 2018). Recently, ontogenesis has also been studied for other tree and herbaceous plants (Khrolenko et al., 2007; Teteryuk et al., 2013; Silayeva, 2014; Lapirov, 2014, 2015; Akhmedov et al., 2016; Evstigneev \& Korotkov, 2016; Kubentaev \& Danilova, 2016; Kirichok, 2016; Martínková \& Klimešová, 2017; Talovskaya, 2017; Borovik \& Revushkin, 2018; Sakhonenko \& Matyukhin, 2018; Belyakov et al., 2018).

There are few reports focused on ontogenesis of representatives of the Sparganium L. genus in the Russian and foreign literature. Mostly they are related to germination of seeds. An overview of germination at initial stages of the development of seedlings (mainly S. emersum Rehm. and S. erectum L.) is given in studies by a number of foreign scientists (Muenscher, 1936; Steinbauer \& Neal, 1950; Ishii et al., 2005; Kim et al., 2017). Studies by Dutch scientists (Pollux, 2011; Pollux et al., 2006 ; 2007) were focused on study of germination of seeds of $S$. emersum as a result of their travelling through the gastrointestinal tract of various agents (birds, fish). A brief description of the ontogenesis of S. emersum was provided in the study by Boiko \& Alekseev (1990). These authors focused their attention on description of the virginile period and generative age states of individuals. We also found pictures of seedlings in a small number of reports (Muenscher, 1944; Cook, 1962; Tillich, 2007). None of the studies on bur-reed (Sparganium) which we have cited contains a detailed description of ontogenetic (age) state.

Sparganium is an ancient genus, most fossil remains of which are known from the Cretaceous Period and the Paleogene (Sulman et al., 2013; Zhou et al., 2018). Representatives of the genus are distributed mainly in the temperate zone of the northern hemisphere, and also in Australia and New Zealand (Leonova, 1982 - as cited in Belyakov \& Lapirov, 2015a). Similarly to other species which belong to the ecological group helophytes, they grow in the shoreline zone of various water bodies (shores of lakes, rivers, shallow-water areas of water reservoirs, ponds, ditches, gutters). At the same time, some of them (for example S. emersum Rehm. and S. erectum L.) are indicators of eutrophic freshwater areas of water bodies with alluvial sediments or substantial silt deposits, whereas other species are oligosaprobic, found in oligotrophic and mesotrophic (for example $S$. gramineum Georgi), as well as meso- 
eutrophic and oligomesotrophic (for example $S$. natans L.) water bodies. Despite the fact that all species of bur-reeds are characteristic of only one living form (herbaceous polycarpic plant; summer-winter green, vegetatively mobile clear polycentric long-root pseudoannual with racemose root system, anisotropic medium-rosette di- and tricyclic vegetativegenerative shoots and leaves floating on the surface; hemicryptophyte), most of them exhibit clear polymorphism. This is manifested in the property of the plants to develop ecological forms which can be above ground, emersed, submerged with leaves floating on the water surface and a completely submerged sterile ecological form (Belyakov \& Lapirov, 2015b; Belyakov \& Philippov, 2018). Development of the latter is the result of the impact of the level regime of water bodies. However, other species can be also found (for example $S$. gramineum) which are characterized by only one ecological form (does not form other ecological forms and/or variations except submerged) (Belyakov \& Lapirov, 2018).

Therefore, the objective of the study was ontogenesis of genets and ramets (on the example of development of tuber-like structures and axillary buds) of representatives of the Xanthosparganium subgenus.

\section{Materials and methods}

Certain stages of ontogenesis were studied in field and laboratory conditions. For the study of the initial stages of the genet's ontogenesis, we used seeds of model species of Sparganium, which after collection were processed in humid cold stratification (at $\mathrm{t}=+3 \ldots+4{ }^{\circ} \mathrm{C}$ over $3-6$ months) (Belyakov \& Lapirov, 2015a). Seeds of S. emersum (the Korozhechna River, near Masalskoe village, Uglichsky District, 23.08.2013), S. gramineum (Riumnikovskoe Lake, near Riumniki village, Rostovsky District, 13.09.2015), S. glomeratum (Laest. ex Beurl.) Neuman (old flooded railway through the forest, east of Goldiaika village, Poshehonsky District, 10.09.2016) and S. natans (water-intake ditch of a sand quarry on the south shore of Chashnitskoe Lake, Rostovsky District, 13.09.2015) were collected in the territory of Yaroslavl Oblast. After cold humid stratification, the seeds were put in Petri dishes on filter paper moistened with tap water, germination took place in a luminostat, at illuminance of $1868 \pm 126.2 \mathrm{~lx}$ (photoperiod 16/8) and temperature from $18.2 \pm 0.9^{\circ} \mathrm{C}$ (morning) to $28.7 \pm 3.0^{\circ} \mathrm{C}$ (evening). Germination took place according to the methods described in the study (Belyakov \& Lapirov, 2015a).

Ontogenesis of genets. Over the first week, from the beginning of germination of seeds, the development of the seedlings in the Petri dishes was monitored daily. Then, the intervals of monitoring were gradually increased to once a week. For morphometric analysis of the seedlings, 5-10 specimens were taken each time. For them, we recorded the beginning of the development of the main and secondary roots, the time of break of cotyledonary sheath by the first assimilating leaf. We measured length of roots, length and diameter of hypocotyl and basal area of the shoot, length and width of laminae, and recorded the number of veins.

Next, some of the plants (until total dying off) were left in Petri dishes, and the remaining plants were planted in two aquariums (depth of water was up to $3 \mathrm{~cm}$ ), out of which the plants were periodically taken ( 5 specimens once in 2 months) for morphological analysis. Two months later, one aquarium was put into a refrigerator, where it was kept at a temperature of $+3 \ldots+4{ }^{\circ} \mathrm{C}$, while the other remained in the luminostat. Four months later, the aquarium from the refrigerator was again put into the luminostat. Further monitoring of the plants was conducted until complete death of the plants.

Study of the initial stages of ontogenesis of $S$. emersum was additionally conducted in the ponds of the experimental pond base "Sunoga" of the Papanin Institute for Biology of Inland Waters of the Russian Academy of Sciences. For this purpose, well developed seedlings of Sparganium (a month after germination in laboratory conditions) were planted in late June into trays made of acrylic glass $(110 \times 8 \times 5.5 \mathrm{~cm})$ with sandy-silt mixture, then they were transferred into a pond with insignificantly running water $(\mathrm{pH}=8.1)$ at a depth of $0.3 \mathrm{~m}$. The water level during vegetative season was constantly under control. In the first decade of September, five plants were taken out of the trays for biomorphological analysis. For normal life over the winter period, the plants which remained in the trays were transferred into a wintering pond at a depth of 1.5-1.8 m. In spring, to continue the observations, we returned the trays to their previous location. We grew the plants over a period of two years. Each year, in the first decade of September or in late May, we selected five plants from the trays for biomorphological analysis.

Ontogenesis of ramets. Ontogenesis of vegetative diaspora, tuberlike structures (TLS), were examined on the example of S. emersum. TLS of this plant were collected in early September on the Korozhechna River. In laboratory conditions, the TLS were kept for two months in a refrigerator in open desiccators filled with water. Then, we planted the TLS into sandy soil of aquariums at a depth of $3 \mathrm{~cm}$. To conduct such morphological analysis, 5 plants were selected from the aquariums once every two weeks. Similarly to the case with studying ontogenesis of genets, the duration of the experiment depended on the time of dying of the shoots.

Further observations on the course of certain stages of ontogenesis were continued in field conditions. Studies of ontogenesis of S. emersum ramets developing on the basis of the terminal buds of the rhizomes, were performed from April to October (twice a month) over 2013-2018 in small rivers of Yaroslavl Oblast: Velikaia (Yaroslavl District), Korozhechna (Uglichsky District), Ild (Nekouzsky District). Studies on S. gramineum, $S$. glomeratum and $S$. natans were performed in the same periods and at the same sites where the seeds for studying initial stages of ontogenesis were collected (see above).

In each period of collecting, 5 to 10 specimens of plants of each species were collected. We took into account phenophase, depth of growth, temperature of water and soil characteristics. In the study, we used standard ontogenetic and comparative-morphological methods of study (Savinykh \& Cheryomushkina, 2015), widely used in the study of aquatic and shoreline-aquatic plants.

Ontogenesis was described from the position of its discrete description, using an earlier proposed scheme of age periodization (Rabotnov, 1950; Uranov, 1975; Smimova, 1976; Komarov et al., 2003). Type of ontogenesis was identified according to the classification of Zhukova (1995).

For the study of the main morphometric parameters of plants, we used binocular microscopes MBS-10 and MSP-2 with micrometric scales. In total, we studied about 80 seedlings and around 50 individuals of each species of Sparganium, which were in different ontogenetic states. Tables in the paper present the data as $\mathrm{x} \pm \mathrm{SD}$. The article provides detailed figures of particular ontogenetic states.

\section{Results}

Study of morpho-functional adaptations of representatives of the genus Sparganium is impossible without detailed analysis of ontogenesis and ontomorphogenesis on the example of the genets and ramets (the development of tuber-like structures and axillary buds of rosette areas of the shoots). For this reason, we performed a study of all possible variants of ontogenesis on the example of representatives of the Xanthosparganium subgenus.

Ontogenesis of individuals of generative origin. Latent period. The process of dissemination of Sparganium begins in late August and lasts until early-mid October. The seed is a dry drupe (Zubkova \& Shabes, 1983; Belyakov \& Lapirov, 2015a) which contains a poorly differentiated baculiform embryo with no chlorophyll (Boiko \& Alekseev, 1990). In the apical part, it is represented by the only cotyledon which serves a haustorial function. In the basal part, the cotyledon bears a well developed sheath, inside of which the embryo's bud is located. The hypocotyl which turns into a quite wide and blunted embryonic petiole is developed poorly.

The embryo is located in well-developed endosperm. Its cells are large, contain protein and starch, and also fatty oils in small amounts; perisperm is one-layered. Its cells are significantly smaller than the cells of the endosperm and contain protein, and also starch and fatty oils (Zubkova \& Shabes, 1983). The endosperm is of helobial type (Anisimova, 1990). Thus, on the basis of the features based on proportion between sizes of embryo and accumulating tissues of the seed (Martin, 1946 - as cited in Crocker \& Barton, 1955), we classify the seed of Sparganium to section III (seeds with axis position of embryos), type A 
(seeds with elongated embryos). We have shown that freshly collected seeds of Sparganium do not germinate (Belyakov \& Lapirov, 2015a), which is conditioned by water-resistance of their coat, as well as the special physiological states of the embryo. Prolonged storage of seeds of Sparganium (over two years) in dry form at room temperature and in a refrigerator gives extremely low indicators of laboratory germination slightly higher than $2 \%$. At the same time, maintenance of seeds in water at temperature around $+3{ }^{\circ} \mathrm{C}$ has a favourable effect on their germination ability. Seeds of $S$. emersum can germinate during 4-5 years, S. glomeratrum - up to $1.8-2.3, S$. natans - 1 to 2 years, and S. hyperboreum - up to 2.3 years. Germination of single seeds of $S$. gramineum was observed during the period of their maintenance of 4 months to 1.8 years. The observations show that the seeds collected in one place in different years (in approximately the same period of time), after stratification in water, begin to germinate at different times, and often show significantly differing maximum parameters of laboratory germination. Thus, for example, the period of beginning of germination of $S$. natans seeds collected in different years can fluctuate from 9 months to 1 year, and the maximum parameter of germination in laboratory is $4.9 \pm 1.6$ to $55.0 \pm 5.0 \%$.

Study on the dynamics of the main parameters of germination of seeds of all the bur-reed species of the Xanthosparganium subgenus (after different periods of cold humid stratification) which we studied demonstrates that they are characterized by a wavy pattern of changes.

Pre-generative period. Spouting of seeds begins from elongation of the cotyledon. Its basal part (with embryo petiole) pushes out the micropyle cover into the cavity of the pericarp, positioned above the micropyle opening of the drupe. Then, the basal end of the cotyledon goes through the micropyle opening and breaks through the membrane of the pericarp which at the base is slightly inclined towards the column. The apical part of the cotyledon remains in the endosperm for several weeks, fulfilling the haustorial function.

By the end of the first 24 hours after the germination, the seedling is represented by the cotyledon which has a notable sheath on the basal end, which contains a bud of the embryo and insignificantly manifested

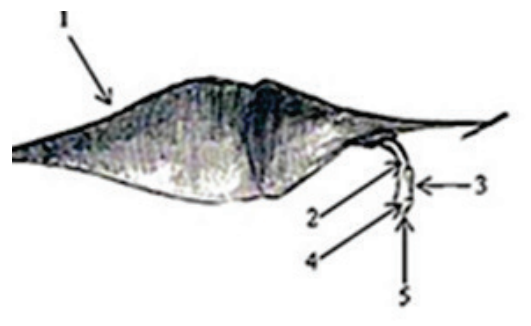

a

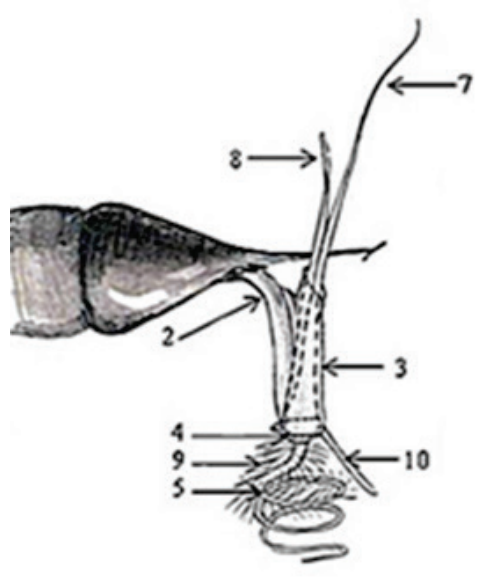

$\mathrm{C}$ hypocotyl which turns into the embryonic (main) root. The cotyledon comprises two parts: the haustorial part, which remains in the drupe, and the assimilating part, which is a bow-shaped bent petiole. Also, according to our observations, the length of the petiole in absence of light can reach $1 \mathrm{~cm}$ among the representatives of the examined subgenus. It should be noted that during the germination of the bur-reed seeds, the cotyledon becomes green (similarly to a number of other aquatic plants, for example Alisma plantago-aquatica L.), which, according to Hohryakov (1975), is caused not by aquatic life, but is a manifestation of a general tendency towards acceleration of the development of the seedlings.

On the second day, on the basal end of the hypocotyls, often a crown of root hairs is formed, which disappears during the further development of the seedling. At the initial stage, these hairs function for strengthening of the seedling in the soil and for absorption of nutrients (Klebs, 1885 - as cited in Vasilchenko, 1936). In this period, the first leaf develops. The second leaf and the following leaves are linear with rounded end, have up to five veins, are thinner and more delicate, sometimes lighter in colour, compared to the first leaf. We should note that the development of each subsequent leaf (after the first) leads to formation of a new non ramifying adventitious root.

Seedling (p). This age state in S. emersum and S. glomeratum in laboratory conditions lasted 36-40 days and slightly longer in the remaining species (S. gramineum, $S$. natans and $S$. hyperboreum) - up to $40-57$ days. The condition is characterized by formation of all organs of the plant (Table 1), ortotrophic growth of the shoot area and the beginning of its thickening. As a result, the seedling is represented by a one-axis rosette shoot with shortened ranked internodes (Fig. 1). As a result of non-uniform ranking of the internodes, the developing shoot obtains a cylindrical form. The number of leaves on the shoot reaches $4-5$, out of which one usually dies. The number of adventitious roots is slightly lower (4 in S. emersum, and 2 and 3 in S. glomeratum and S. natans respectively), at the same time, the third adventitious root becomes the longest. During that period, the main, and often the first, adventitious roots die. The dying of the cotyledonary petiole contributes to the transition of a plant into the following age state.

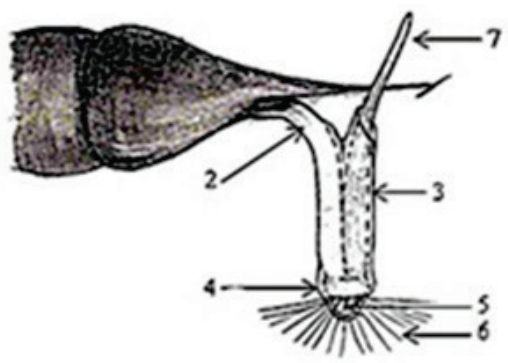

b

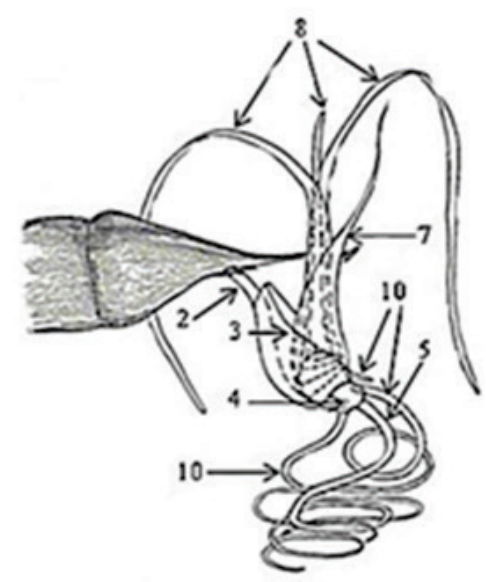

d

Fig. 1. Phases of development of seedlings on the example of $S$. emersum $(a, b, c, d)$ :

1 - seed; 2 - cotyledonary petiole (connective of the cotyledon); 3 - cotyledon sheath; 4 -hypocotyl; 5 - embryonic root (main root); 6 - crown of root hairs; 7-8 - the first and the second assimilating leaves (respectively); 9 - root hairs; 10 -adventitious root 
Table 1

Morphological parameters of the elements of the shoot sphere of seedlings of some species of Xanthoparganium subgenus

\begin{tabular}{|c|c|c|c|c|c|c|}
\hline \multirow{2}{*}{\multicolumn{3}{|c|}{ Morphological parameters, $\mathrm{cm}$}} & \multicolumn{4}{|c|}{ Species of Sparganium } \\
\hline & & & \multirow{2}{*}{$\begin{array}{l}\text { S. emersum } \\
0.16 \pm 0.06\end{array}$} & \multirow{2}{*}{$\frac{\text { S. glomeratum }}{0.28 \pm 0.04}$} & \multirow{2}{*}{$\begin{array}{c}\text { S. gramineum } \\
0.26 \pm 0.06\end{array}$} & \multirow{2}{*}{$\begin{array}{c}\text { S. natans } \\
0.31 \pm 0.02\end{array}$} \\
\hline Cotyledonary petiole & & $l$ & & & & \\
\hline (connective of the cotyledon) & & $d$ & $0.02 \pm 0.00$ & $0.03 \pm 0.00$ & $0.03 \pm 0.02$ & $0.02 \pm 0.00$ \\
\hline Length of cotyledon sheath & & & $0.20 \pm 0.04$ & $0.14 \pm 0.02$ & $0.14 \pm 0.02$ & $0.17 \pm 0.03$ \\
\hline \multirow[t]{3}{*}{ Length of the main root } & & & $1.55 \pm 0.57$ & $1.61 \pm 0.34$ & $0.47 \pm 0.17$ & $1.50 \pm 0.27$ \\
\hline & & 1 & $2.46 \pm 1.00$ & $0.66 \pm 0.25$ & $1.53 \pm 0.77$ & $1.16 \pm 0.21$ \\
\hline & & 2 & $1.87 \pm 0.67$ & $1.06 \pm 0.51$ & $1.07 \pm 0.58$ & $0.36 \pm 0.20$ \\
\hline \multirow[t]{8}{*}{ Length of adventitious roots } & & 3 & $1.09 \pm 0.44$ & $1.08 \pm 0.53$ & $0.51 \pm 0.41$ & $0.76 \pm 0.15$ \\
\hline & & 4 & $0.61 \pm 0.40$ & $0.96 \pm 0.47$ & $0.26 \pm 0.16$ & $0.93 \pm 0.54$ \\
\hline & & 5 & $0.41 \pm 0.22$ & $0.65 \pm 0.55$ & $0.32 \pm 0.20$ & $0.30 \pm 0.16$ \\
\hline & 1 & $l$ & $1.80 \pm 0.22$ & $1.40 \pm 0.30$ & $0.91 \pm 0.15$ & $2.00 \pm 0.30$ \\
\hline & $?$ & $l$ & $3.10 \pm 0.72$ & $2.24 \pm 0.50$ & $1.46 \pm 0.06$ & $3.40 \pm 0.61$ \\
\hline & 2 & $w$ & $0.11 \pm 0.04$ & $0.07 \pm 0.01$ & $0.06 \pm 0.00$ & $0.08 \pm 0.00$ \\
\hline & 3 & $l$ & $3.65 \pm 0.86$ & $1.74 \pm 0.32$ & $1.10 \pm 0.27$ & $3.08 \pm 0.67$ \\
\hline & 3 & $w$ & $0.11 \pm 0.03$ & $0.07 \pm 0.01$ & $0.05 \pm 0.00$ & $0.08 \pm 0.01$ \\
\hline \multirow[t]{6}{*}{ Sizes of assimilating leaves } & & $l$ & $2.11 \pm 0.86$ & $1.40 \pm 0.40$ & $0.33 \pm 0.10$ & $2.41 \pm 0.33$ \\
\hline & 4 & $w$ & $0.07 \pm 0.01$ & $0.06 \pm 0.01$ & $0.04 \pm 0.00$ & $0.07 \pm 0.00$ \\
\hline & & $l$ & $1.11 \pm 0.40$ & $1.54 \pm 0.20$ & - & $1.87 \pm 0.30$ \\
\hline & 5 & $w$ & $0.05 \pm 0.01$ & $0.05 \pm 0.00$ & - & $0.07 \pm 0.00$ \\
\hline & & $l$ & - & - & - & $1.97 \pm 0.58$ \\
\hline & 6 & $w$ & - & - & - & $0.07 \pm 0.00$ \\
\hline \multirow{2}{*}{ Sizes of the rosette area of the shoot } & & $l$ & $0.17 \pm 0.04$ & $0.14 \pm 0.01$ & $0.10 \pm 0.01$ & $0.23 \pm 0.02$ \\
\hline & & $d$ & $0.06 \pm 0.01$ & $0.06 \pm 0.01$ & $0.08 \pm 0.01$ & $0.07 \pm 0.00$ \\
\hline
\end{tabular}

Notes: $l$-length, $d$-diameter, $w$ - width, “-“-no data.

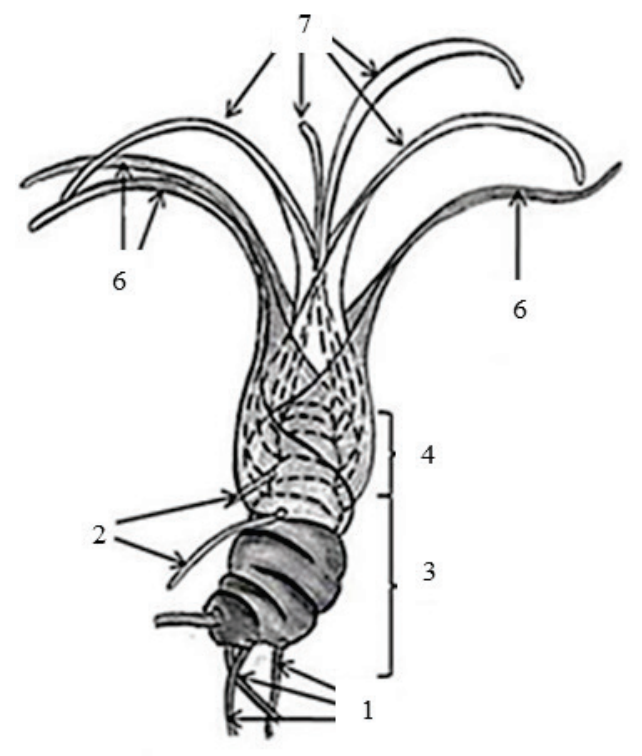

a

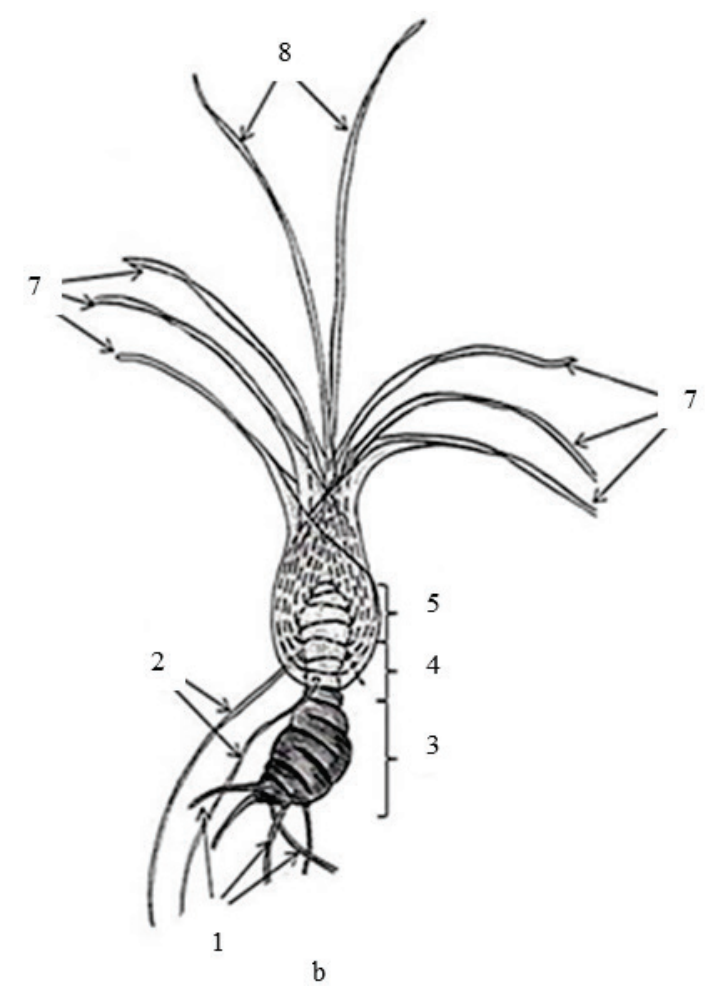

Fig. 2. Genet of S. emersum in juvenile age state $(a)$ and in juvenile age state at the stage of forming of a new elementary shoot $(b)$ :

1 -adventitious roots which have died; 2 - live adventitious roots; 3 - rosette area of the shoot with metamers of larger diameter; 4-rosette area of the shoot with metamers of smaller diameter; 5 - newly formed area of the rosette shoot (elementary shoot) with metamers of larger diameter (compared to previous); 6 - dead shortened leaves; 7 -live shortened leaves; 8 -young long leaves

Juvenile age state (j). In this age state, the first shortened leaves appear, which significantly differ from the previous leaf sequence (long leaves). They are linear, dark-green, leathery, with rounded apex, of 0.6 $\pm 0.2 \mathrm{~cm}$ length (however, their sizes can exceed $1.0 \mathrm{~cm}$ ).

On days 60-70, the number of shortened leaves on the shoot reaches 5-6. At the same time, formation of new shortened leaves is accompanied by dying of the earlier formed long and 1-2 first shortened leaves (Fig. 2a). The rosette part of the shoot has a cylindrical shape and is composed of two areas which differ in diameter of internodes - metamers of larger diameter $(0.12 \pm 0.02 \mathrm{~cm}$ in $S$. emersum and S. glomeratum, up to $0.06 \mathrm{~cm}$ in $S$. natans) are gradually replaced by metamers of smaller diameter $(0.07 \mathrm{~cm}$ in $S$. emersum and $S$. glomeratum, up to $0.03 \mathrm{~cm}$ in $S$. natans). From the nodes of the latter, shortened leaves protrude. We found no buds in axils of leaves of all types.

The maximum number of adventitious roots on the shoot during this period equals 6-8. Their length changes along a double-peak curve. The first peak indicates active growth of root system, which is related to intense growth of the shoot. The subsequent reduction of linear sizes of roots is conditioned by decrease in tempi of growth of the shoot, and, it seems, its transition into the phase of rest. We should note that the roots on the shoot develop not only on the leaf-bearing area, but also higher up- in the area with shortened leaves. Dying of adventitious roots on the 
first area occurs by days 70-90. The capacity of the terminal bud of the main shoot by the end of the juvenile age state reaches $6.3 \pm 0.4$ primordial leafs.

Over this period, the plants which had been kept in laboratory conditions (Petri dishes) often completely died. We conducted further research on ontogenesis of the representatives of Xanthosparganium subgenus on aquarium and pond culture of S. emersum. Therefore, ontogenesis of plants from generative primordial leafs in laboratory conditions is interrupted.

In aquariums, further development of the main shoot of $S$. emersum was accompanied by notable growth of primary thickening and uncoiling of new 4-5 long leaves (up to $2.0-3.5 \mathrm{~cm}$ ) (Fig. 2b). At the same time, between the previous and newly formed areas (including the metamers of larger diameter $-0.10-0.12 \mathrm{~cm}$ ), the part of the shoot which was composed of metamers of smaller diameter (on which the shortened leaves were located earlier) became noticeable. At this stage, the plants development in aquariums stopped and the plants died.

Thus, despite the early death of plants in Petri dishes and aquarium culture, their development indicated that practically by the end of the first year of their life (over 6-8 months), the plants can realize two age states of pre-generative period of ontogenesis (seedling and juvenile plant). At the same time, the annual shoot (terminology of Serebrjakov, 1952 ) is actually represented by two elementary shoots (rhythmic shoots, terminology of Grudzinskaya, 1960). The first comprises metamers of larger diameter and bears long leaves, the second - metamers of smaller diameter and shortened leaves. Despite the fact that formation of next annual shoot, as the development of plants in aquariums had demonstrated, is possible during the first year of their life, in natural conditions this process occurs in the second vegetative season along with spring growth of the shoot.

Another situation was observed in the experimental ponds (conditions close to natural). There, the development of S. emersum was much quicker. Already a month after the transportation into the pond, the plants move into juvenile ontogenetic condition. In the first decade of September (first vegetative period), the plants formed an anisotropically and monopodially growing vegetative rosette shoot (the first elementary shoot, similar in structure to the one described above) which bore 10-11 long leaves submerged in water $(10.0$ to $24.5 \mathrm{~cm}$ in length, and 0.27 $0.35 \mathrm{~cm}$ in width). The vast majority of plants were observed to have 3 4 side buds (in axils of 4 th to 6 th leaves from the basal end), with capacity of up to 6 primordial leafs. Some of the specimens we studied had a developing short geophilous shoot (4 metamers of up to $2.7 \mathrm{~cm}$ length and $0.04 \mathrm{~cm}$ diameter) on the base of one of the buds (in axil of 5th to 6th leaf), which had a poorly developed terminal tuber-like structure on the end (Fig. 3). The capacity of the apical bud of the main shoot during that period reaches $8 \pm 1$ primordial leafs. This suggests that some of the strongest plants in the end of the vegetative season can revert to immature ontogenetic state.

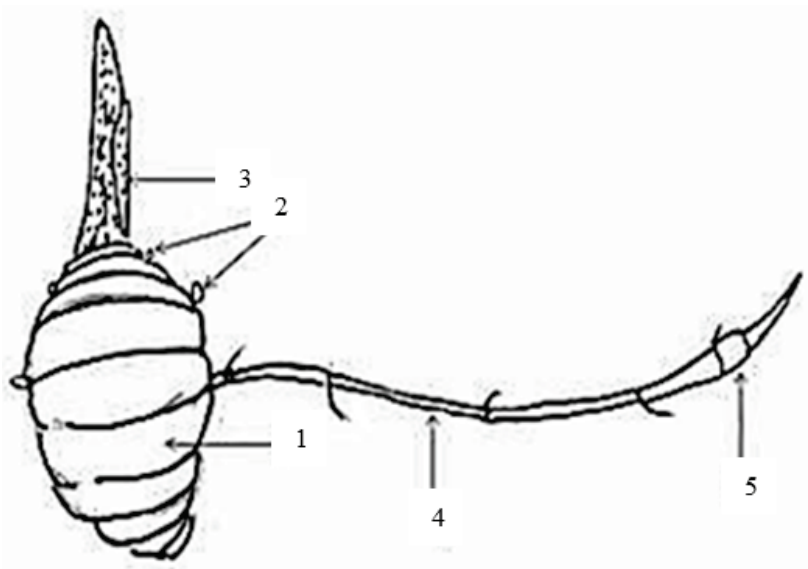

Fig. 3. Genet of S. emersum at the end of the first year of the development (adventitious roots and leaves are deleted):

1 -rosette shoot; 2 - axillary buds; 3 - apical bud;

4 -geophilous shoot; 5 - terminal tuber-like structure
Therefore, in laboratory conditions, the juvenile ontogenetic condition is characterized by slowing of the development of plants and lasts 40-50 days. Shortening of leaf length and reduction of the diameter of the rosette part of the shoot can indicate its transition to a state of rest. Such feature is characteristic of plants of seasonal climates. In natural conditions, duration of this age state can reach $1.0-1.5$ years.

Immature age state (im). In conditions close to natural, the vast majority of the plants moved to immature ontogenetic state early in the second vegetative season in the process of formation of new (first, in the second season) elementary shoots. Already by mid-June, they had up to 6 long leaves (of $18.0-26.0 \mathrm{~cm}$ length, and $0.2-0.25 \mathrm{~cm}$ width), in the axils of which, 2 to 5 buds developed.

This age state is characterized by presence of a clearly distinct structure of the rosette part of the mother shoot. In its basal part, there is a newly formed area of the rosette shoot with larger diameter, beginning from 3-4th metamer which bears side buds. We should note that the first (the lowest) bud does not develop and remains dormant. One or two subsequent buds form geophilous shoots ( 4 metamers of $4.0 \pm 1.2 \mathrm{~cm}$ length and $0.07 \pm 0.01 \mathrm{~cm}$ in diameter) which have terminal tuber-like structures on the end. The rest (positioned above) of the side buds do not develop. The capacity of the lowest not realized side bud reaches 8-9 primordial leafs.

Yong vegetative age state $\left(v_{0}\right)$. Transition to this ontogenetic state is related either to the following development of the apical bud of the tuber-like structure, or apical bud of the mother shoot.

In the first case, a daughter rosette shoot actively develops, which gains possession of nutrients of the mother shoot (Fig. 4). The latter significantly reduces the intensity of growth, and often leads to the end of the vegetative season.

In the second case - gaining possession of the flow of nutrients to the mother shoot does not occur. The latter actively develops, whereas the daughter rosette shoot formed on the base of the apical bud of the terminal tuber-like structure dies.

By the end of the second year of development, newly formed rosette areas of the shoots (regardless of the origin - either from the apical bud of the mother shoot, or from the apical bud of the TLS) are similar to one another morphologically. They bear up to 9-11 leaves (out of them 5-6 are assimilating; the rest have died off) of $52.2 \pm 4.4 \mathrm{~cm}$ in length and up to $0.3 \mathrm{~cm}$ in width, which reach the water surface. The plants do not form aerial leaves. The plant forms $44.4 \pm 5.0$ adventitious roots, maximum length of which equals $12.2 \pm 1.8 \mathrm{~cm}$. We should note that the size characteristics of the previous year's area of the mother shoot $(0.31 \pm 0.02 \mathrm{~cm}$ length and $0.27 \pm 0.01 \mathrm{~cm}$ diameter) were lower compared to the rosette areas of that year $(0.37 \pm 0.03 \mathrm{~cm}$ in length and $0.34 \pm 0.01 \mathrm{~cm}$ in diameter).

In its basal part, the rosette areas of the shoot of the current year, starting from metamers 3-4, had side buds. Their subsequent development was the same as in similar structures in immature age state. At the same time, the capacity of the lowest of them reached 10-11 primordial leafs. The capacities of the rest (located higher) decreased, on average by two primordial leafs. We did not observe the subsequent development of the individual of seed origin, though in our opinion it is possible.

We presume that the development of S. emersum, similarly to other species we studied, can take its course through formation of a tricyclic vegetative-generative shoot in the following way: young vegetative age state $\left(\mathrm{v}_{1}\right) \rightarrow$ adult vegetative $\left(\mathrm{v}_{2}\right) \rightarrow$ cryptogenerative $\left(\mathrm{g}_{0}\right) \rightarrow$ generative $(\mathrm{g})$.

Ontogenesis of an individual of vegetative origin. Vegetative reproduction and distribution is especially important for plants with inhibited seed reproduction. In natural conditions, the European burreed (S. emersum), and also a number of other representatives of this subgenus (for example, $S$. natans and $S$. glomeratum, $S$. gramineum) by autumn form tuber-like structures, young vegetative diasporas.

Let us analyze the individual development of bur-reed out of TLS on the example of S. emersum.

Latent period. Presence of dormant TLS can be observed already in late August-early September. Sometimes, TLS of S. emersum form hypogeogenic rhizomes at the apical end (further, we will refer to them as terminal TLS). However, most often they can be found at the apexes 
of shortened side shoots (rhizomes) of $n+1$ and $n+2$ orders. The latter develop out of buds in the axils of scale leaves of communicator rhizomes. TLS of brown colour are spindle-shaped and are an apical bud of the rhizome, the axis of which spreads out and parenchymizes. The expanded part of the terminal tuber-like structure is usually represented by two basal shortened metamers which bear scale leaves in the nodes. The lower (first) scale-resembling leaf of the TLS (1.0 cm in length) completely covers the first internode and partly covers the second one. The second scale-resembling leaf (up to $0.8 \mathrm{~cm}$ ) completely covers the next internode and almost the entire apical bud of $2.9 \pm 0.8 \mathrm{~cm}$ length. The axils of both scale-resembling leaves contain buds which usually do not grow. By late September, the apical bud had capacity of 6-7 primordial leafs, in October - 10-11, and by December, the number of primordial leafs had increased to 14 .

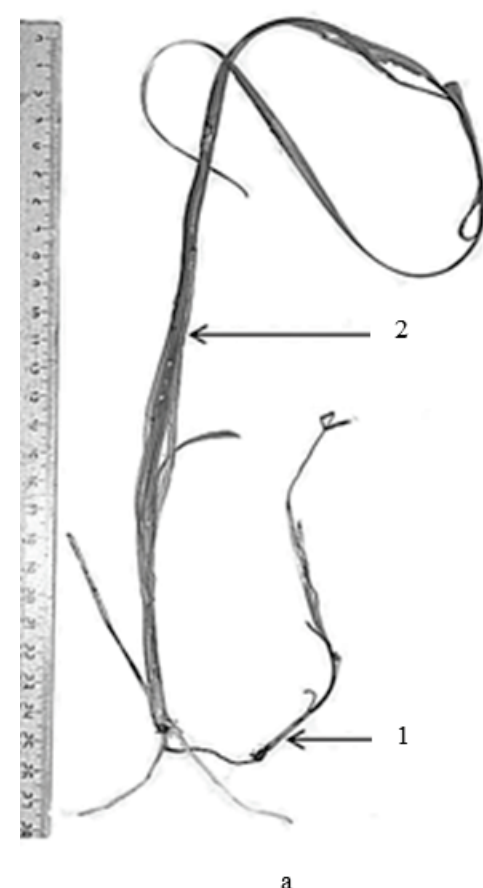

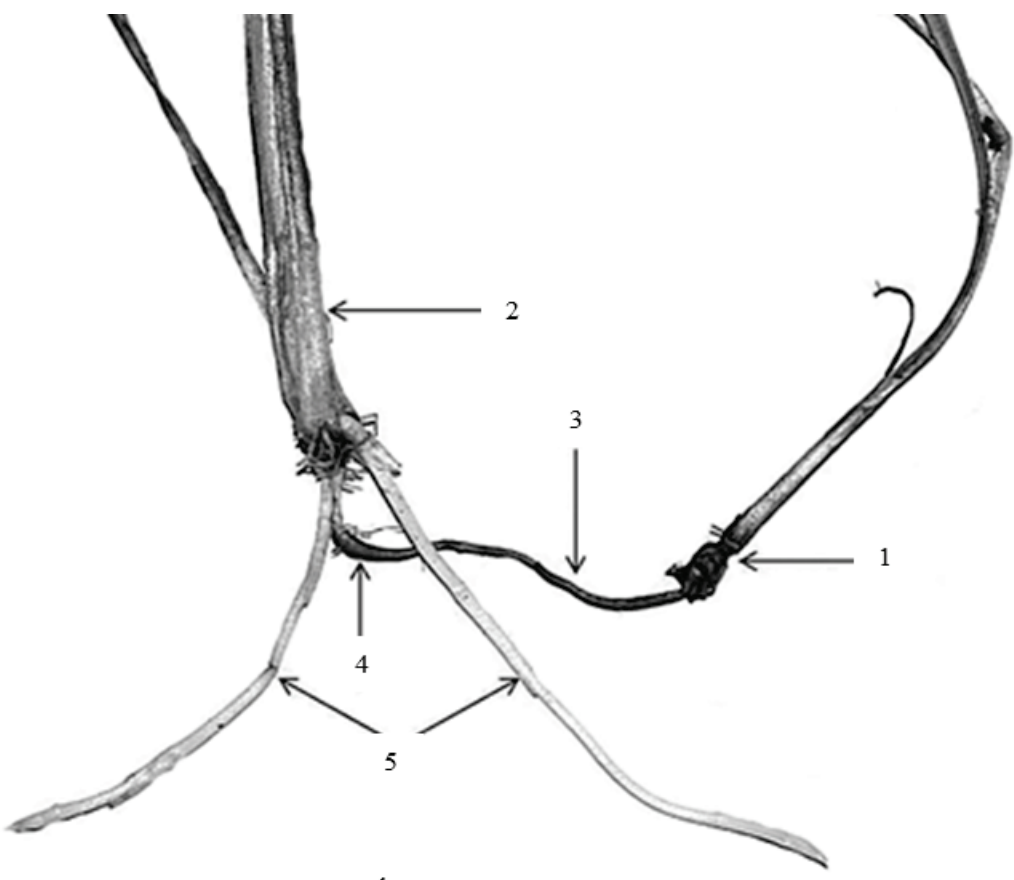

$\mathrm{b}$

Fig. 4. Genet of S. emersum in the second year of life (adventitious roots are deleted) (a); structure of shoot system (leaves and roots are deleted) (b): 1 -mother rosette shoot; 2 - daughter rosette shoot; 3 -rhizome of previous year; 4 -terminal tuber-like structure formed over the previous year; 5 -rhizomes of current year of the development

Because in natural conditions, the initial stages of the development of TLS are hard to monitor, we performed observations in aquarium culture in a laboratory.

Juvenile age states. In laboratory conditions, we recorded beginning of the development of the European bur-reed at 3-4th day after planting TLS into the aquariums. The development of the shoot from the apical bud of TLS at first was accompanied by formation of an area represented by $3-4$ short metamers $(0.03-0.04 \mathrm{~cm}$ in length and up to $0.10-0.15 \mathrm{~cm}$ in diameter). The nodes of short metamers bear scale leaves (up to $1.2-1.5 \mathrm{~cm}$ in length), the axils of which had side buds which usually do not develop and remain dormant. Along this entire area of the shoot, stem-type adventitious roots form of up to $4.5-6.5 \mathrm{~cm}$ in length. At the same time, the shoot grows anizotropically and monopodially. Further the growth of primary thickening occurs, as a result of which, a rosette shoot forms. At first, up to 3 transitional leaves (of $1.8 \pm$ $0.7 \mathrm{~cm}$ length) uncoil, differing from the leaves of middle formation by presence of sheath of large sizes (over $3 / 4$ of the leaf length). One week later, the first leaves of the middle formation develop (up to 12.0-12.5 cm in length, and 0.15 to $0.20 \mathrm{~cm}$ in width). The latter look similar (apart from size characteristics) to the submerged leaves or leaves floating on the water surface, which the adult plants have (Fig. 5).

Immature age state. Three months later, we found side buds (with maximum capacity of no more than 5 primordial leafs) in axils of all types of leaves of rosette area of the shoot. These buds characterize the process of ramification of the shoot. In conditions of aquarium culture, these buds do not grow. The rosette area of the shoot reaches length of $0.17-0.25(0.30) \mathrm{cm}(0.20 \pm 0.03$ in diameter $)$ and bears up to 9-10 leaves (14.3 \pm 6.5 in length and up to $0.1 \mathrm{~cm}$ in width). The number of roots (of up to $15 \mathrm{~cm}$ length) over that period reached 10 . In the 4 th month of their development, a new area of shoot forms (of up to $0.07 \mathrm{~cm}$ length), having smaller diameter of its metamers $(0.05 \pm 0.01 \mathrm{~cm})$ compared to the previous ones. It bears 5 shortened leaves of up to $0.7-$ $1.4 \mathrm{~cm}$ length, and $0.07 \mathrm{~cm}$ width (Fig. 6a). The latter are in all characteristics the same as the similar shortened leaves which develop among individuals of generative origin (see above). In the fifth month, we again observed significant increase in the length of the leaves $(3.0-4.0 \mathrm{~cm}$ in length and $0.1 \mathrm{~cm}$ in width) It was accompanied by the growth of strengthening. The latter contributes to the formation of new elementary shoot with larger diameter of metamers (Fig. 6b). At this stage of their development, the aquarium culture died.

Thus, in the conditions of aquarium culture, the plant develops during 5 months. Over that period, a shoot forms, the structure of which repeats that of a juvenile plant of generative origin. Also, in individuals which develop from vegetative diasporas (TLS), over one vegetative season, one can monitor formation of two types of elementary shoots - with larger and smaller diameter of its metamers. At the same time, the relationship with TLS remains.

In natural conditions, the main way of restoration and preservation of the populations of the studied species of Sparganium is formation of new individuals of vegetative origin out of axillary buds of forb rosette areas of mono- and dicyclic vegetative and di- and tri-cyclic vegetativegenerative shoots. Their individual development is described below.

Latent period. The duration of the period is related to the time of initiation of a particular axillary bud in a rosette area of the shoot. As is known, the development of the sympodial shoot system of Sparganium takes place sylleptically. Thus, the period of rest of axilary buds of diand monocyclic shoots (which form on the base of a tricyclic vegetative-generative shoot) which form over summer months is reduced to a minimum - approximately to $1.0-1.5$ months. At the same time, the terminal bud of a developing rosette shoot already contains axillary daughter buds (the so-called phenomenon of "buds within a bud"). The state of rest of the axillary buds which are initiated in autumn in the apex of a 
bud of what is still the dicyclic vegetative shoot (which will develop into the phase of vegetative-generative tricyclic shoot in the following year) continues from autumn to spring and lasts up to 7-8 (9) months. Over that period, leaf embryos accumulate in the axillary buds. Their quantity in a bud (by the beginning of its uncoiling) reaches 10-12 (14) (9-10 of them are primordial leafs of scale leaves).

Juvenile age state. As a result of uncoiling of the axillary bud of the rosette area of the shoot, a horizontal fragment of hypogeogenic rhizome forms. Sometime later, its apical bud changes the growth orientation from plagiotrophic to anisotrophic and rises closer to the soil surface. At the same time, the apical bud protected by scale-resembling leaves rises to the substrate surface. As the first scale leaves at the terminal end of the rhizome uncoil, as a result of growth of strengthening, a rosette area of shoot begins to form. The axils of all uncoiling leaves bear side buds.

By the end of this age state, the rosette shoot bears 5-6 leaves ( 3 of the lower formation (scale leaf) and 2-3 leaves which have transitional features of organization - from scale to normally developed leaves (Belyakov \& Philippov, 2018)). The axils of the leaves bear buds. The capacity of the apical bud of the rosette shoots of the studied Sparganium reaches 9-10 primordial leafs. The quantity of adventitious roots (which develop on the base of the rosette shoot) varies quite significantly in different species. Their length rarely exceeds $10-11 \mathrm{~cm}$. We should note that $S$. natans (similarly to $S$. hyperboreum), unlike the rest of the studied species, has lower quantitative and size parameters of the rosette shoot. The latter is related to small sizes of this plant. Thus, by the end of this age state, we can observe beginning of the formation of upperrosette type of shoot. At the same time, its connection with the rosette shoot of the previous year remains.

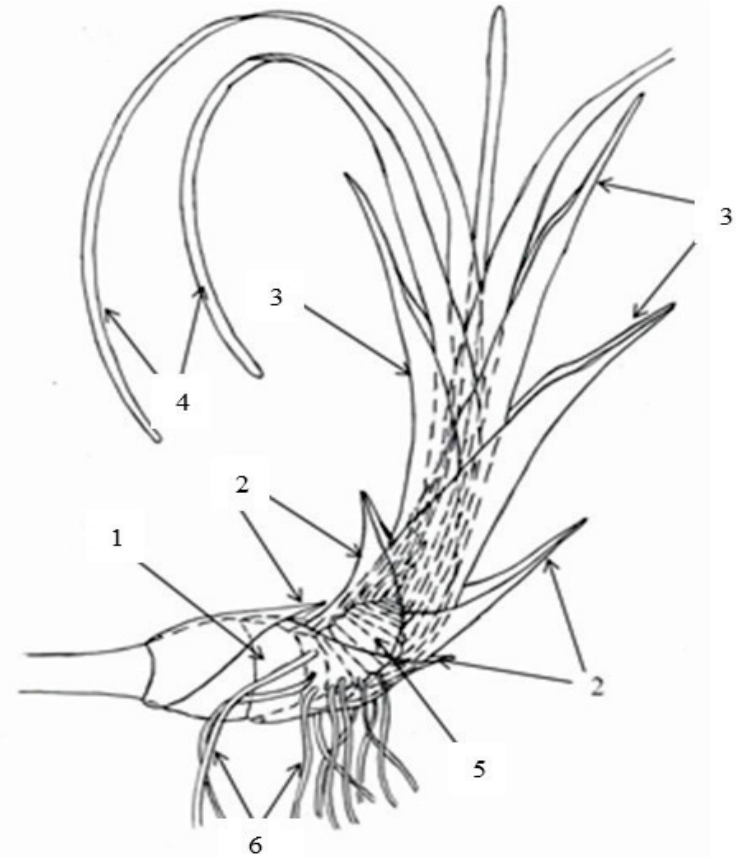

Fig. 5. Ramet of S. emersum in juvenile condition: 1 -tuber-like structure; 2 - scale-like leaves (cataphylls); 3 - leaves of transitional type; 4 - leaves of middle formation; 5 - rosette area of the shoot which is being formed; 6 -adventitious roots

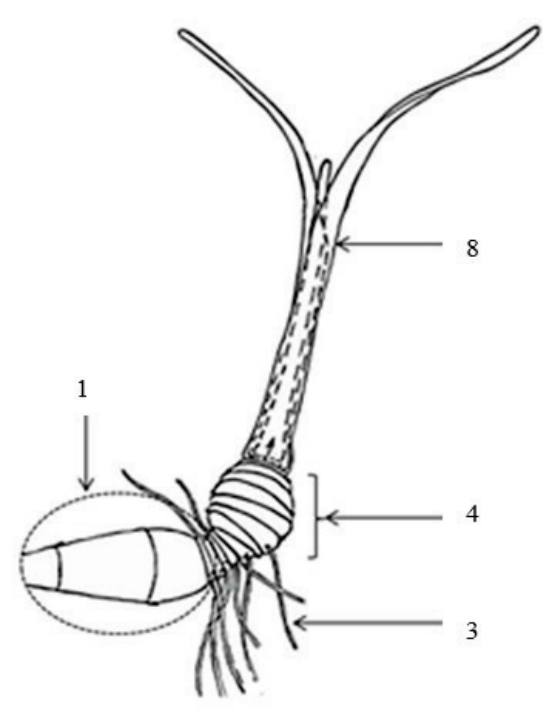

a

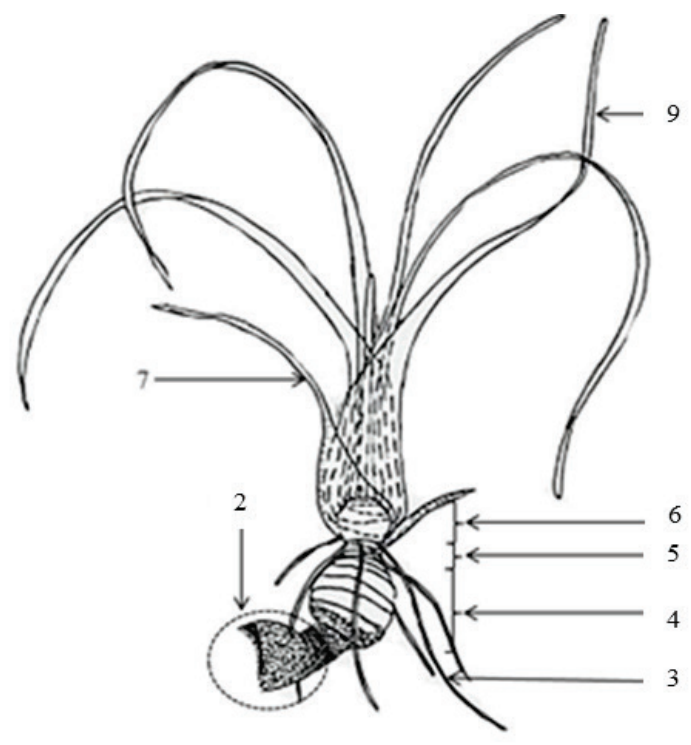

$\mathrm{b}$

Fig. 6. The development of an individual of vegetative origin (from tuber-like structures) in juvenile period of ontogenesis (all explanations are in the text): $a$-fourth month of development (leaves on the shoot are deleted); $b$-fifth month of the development: 1 -tuber-like structure; 2 -dying tuber-like structure; 3 -adventitious roots; 4 - rosette area of the shoot with larger diameter of metamers; 5 -area of the shoot with metamers of smaller diameter; 6 - newly formed rosette area of the shoot with metamers of larger diameter; 7 - dead shortened leaves; 8 -assimilating shortened leaves; 9 - long assimilating leaves (of middle formation)

Immature age state lasts no longer than one week. It is characterized by the beginning of the development of the first sylleptic geophilous shoots (the first of them forms out of side bud positioned in the axil of the 2-3rd scale-like leaf) from the lower side buds initiated in juvenile ramets. Compared to the previous age state, during that period, the rosette shoot bears 7-8 leaves, whereas the number and length of adventitious roots increases by 1.5-2.0 times, and the beginning of their ramification was observed to $n+1$ order (Table 2 ). The capacity of the apical bud of the main shoot reaches 10-11 (12) primordial leafs. All plants which we studied (compared to the previous age states) were observed to have an almost twofold increase in the diameter of the rosette area. Length of the basal rosette areas of the shoots of $S$. natans (submerged form and form with leaves floating on water surface) and $S$. gra- mineum (which only has the form with leaves floating on water surface) increases by two times in this age state, whereas it increases only by 0.2 $\mathrm{cm}$ on average in $S$. emersum and S. gramineum.

We should note that different types of shoots (mono-, di- and tricyclic), formed out of axillary buds, undergo the abovementioned ontogenetic states (latent, juvenile, immature) in accordance to the same "scenario" (see above).

We monitored the further course of ontogenesis on the example of axillary buds of tricyclic vegetative-generative rosette shoots, because out of them the systems of dicyclic vegetative-generative, as well as di- and mono-cyclic systems of vegetative shoots form.

Formation of juvenile and immature ramets is related to the phenomenon of polyvariance in tempi of the development ("dynamic polyva- 
riance" - terminology of Zhukova, 2001) and depends on which axillary buds of tricyclic vegetative-generative rosette shoot they develop from. If the immature ramet forms out of two lower axilary buds of the rosette area of a tricyclic vegetative-generative shoot, then, by omitting the virginile ontogenetic condition, it can directly begin the initiation and the following development of the terminal inflorescence. At the same time, the plant transforms into discretely generative, and then into generative ontogenetic condition. Thus, dicyclic vegetative-generative semi-rosette shoots develop. This ability is characteristic of all representatives of the Xanthosparganium subgenus. In different cases, the ontogenesis of the ramets which develop on the base of the above-located axillary buds of tricyclic vegetative-generative rosette shoots, in the conditions of central Russia usually occurs in another way, when the juvenile ramet transforms into virginile ontogenetic condition.

Virginile age state. Transition into virginile ontogenetic condition in the studied species of Sparganium takes place at the moment of formation (over the vegetative season) at the apical end of the first realized geophilous rhizome (of $n+1$ order) of the anchor shoots and continues until the beginning of the next vegetative season. Each of newly formed rosette anchor shoots is a partial bush, which in turn undergoes its own development cycle (either complete or incomplete). At the same time, the formation of the rhizomes out of axillary buds positioned higher on the rosette shoot continues. All rosette shoots formed at the ends of the rhizomes of $n+1$ order form rhizomes of the following orders of ramification, also terminating by the anchor shoots.

By the end of the vegetative season, the virginile ramet forms out of 8 to 14 (in some cases up to 20) leaves which reach their maximum length and width (Table 2). The number of adventitious roots increases by 1.5 2.0 times compared to the previous age state, and their length practically always reaches its maximum sizes. The roots ramify to $n+2-3$ order. The length of the basal part of the rosette shoot of S. emersum, S. glomeratum and $S$. gramineum increases almost by two times, whereas in both ecological forms of $S$. natans it increases approximately by $0.2 \mathrm{~cm}$. Growth of the diameter of the basal areas of the rosette shoots of the studied species also occurs on average by $0.2 \mathrm{~cm}$. The capacity of the apical bud of the virginile ramet does not change significantly compared to the juvenile age state. By the end of the vegetative season, at the base of the virginile ramet, 3-6 lower axillary buds develop, out of which shoots of the next orders of ramification grow. At the same time, the sympodial system forms, represented by rosette shoots of different orders of ramification (up to orders $n+3-5)$. By autumn, axillary TLS often form out of axillary buds of the rhizomes. Thus, the virginile ramet $\left(\mathrm{v}_{1}\right)$ is a clearly polycentric formation. In this state they winter.

At the beginning of the next (III year of development), the virginile ramet $\left(\mathrm{v}_{2}\right)$ forms, which is different from the previous one $\left(\mathrm{v}_{1}\right)$ in that the main axis of the initial shoot forms a new rosette part of the shoot while continues to grow ortotropically and monopodially. While new geophilous shoots (of the rhizomes) uncoil from its axillary buds, the terminal inflorescence is initiated in the apical bud of the main shoot. Ramets proceed into the generative period of ontogenesis (which lasts up to 2.5-3.0 months), and the cryptogenerative age state lasts usually less than a month. Generative age state is related to the transition of the shoot to blooming and fructification. This transition leads to no significant structural reorganizations of the shoot system of the generative ramets. Therefore, we consider it incorrect to divide the generative period of ontogenesis into a number of ontogenetic age states, and we will only distinguish the phases of blooming and fructification of a generative ramet (Table 2).

We should note that during the generative period of ontogenesis, the dicyclic vegetative shoot differs from the tricyclic only by the fact that the first has only one rosette area of the shoot. Furthermore, the ontogenesis of ramets which emerge from the upper axillary buds of dicyclic vegetativegenerative, and also di- and monocyclic vegetative rosette shoots, usually correspond to the variant which is characteristic of tricyclic vegetativegenerative shoot and undergo all ontogenetic age states.

In autumn, all leaves and inflorescences of tricyclic vegetative-generative shoot die similarly to the leaves of the anchor shoots (of different orders of ramification). Only their rosette parts remain in the soil, connected with one another and with the initial shoot by the system of communicatory rhizomes with axillary TLS. The latter can be found in geophilous areas of the rhizomes of all orders of ramification (up to 4th in each order of ramification). Thus, for example, around 180-250 TLS can form on the rhizomes realized during one vegetative season, on the base of tricyclic vegetative-generative shoot of S. emersum.

At the end of the second - beginning of the third year of development, the researched species of Sparganium were observed to have complete normal specified morphologic fragmentation - vegetative reproduction with formation of certain clones. In general, the entire course of ontogenesis of the Xanthosparganium subgenus representatives we studied can be depicted in the following scheme (Fig. 7).

Table 2

Main characteristics of ontogenetic age state of the shoots which form on the base of terminal buds of rhizomes

\begin{tabular}{|c|c|c|c|c|c|c|c|c|c|}
\hline \multirow{3}{*}{$\begin{array}{l}\text { Ontogenetic } \\
\text { age state }\end{array}$} & \multicolumn{7}{|c|}{ Rosette part of the shoot } & \multirow{3}{*}{$\begin{array}{l}\text { Capacity of } \\
\text { the apical bud }\end{array}$} & \multirow{3}{*}{$\begin{array}{l}\text { Length of the } \\
\text { inflorescence } \\
\text { axis, cm }\end{array}$} \\
\hline & \multicolumn{2}{|c|}{ basal area of the rosette shoot } & \multirow{2}{*}{$\begin{array}{c}\text { number } \\
\text { of leaves }\end{array}$} & \multirow{2}{*}{$\begin{array}{c}\text { length } \\
\text { of leaves, } \mathrm{cm}\end{array}$} & \multirow{2}{*}{$\begin{array}{c}\text { width } \\
\text { of leaves, } \mathrm{cm}\end{array}$} & \multirow{2}{*}{$\begin{array}{l}\text { number } \\
\text { of roots }\end{array}$} & \multirow{2}{*}{$\begin{array}{c}\text { length } \\
\text { of roots, } \mathrm{cm}\end{array}$} & & \\
\hline & length, $\mathrm{cm}$ & diameter, $\mathrm{cm}$ & & & & & & & \\
\hline \multicolumn{10}{|c|}{ S. emersum } \\
\hline$j$ & $0.50 \pm 0.08$ & $0.33 \pm 0.07$ & $6.0 \pm 0.6$ & $15.8 \pm 5.4$ & $0.34 \pm 0.05$ & $19.7 \pm 9.4$ & $6.0 \pm 2.8$ & $9.5 \pm 0.7$ & - \\
\hline im & $0.70 \pm 0.06$ & $0.55 \pm 0.04$ & $7.6 \pm 0.8$ & $31.5 \pm 7.3$ & $0.72 \pm 0.07$ & $39.7 \pm 12.4$ & $12.3 \pm 3.1$ & $11.0 \pm 1.0$ & - \\
\hline$v$ & $1.73 \pm 1.12$ & $0.73 \pm 0.16$ & $11.7 \pm 2.0$ & $45.2 \pm 14.0$ & $0.97 \pm 0.20$ & $67.7 \pm 20.7$ & $30.8 \pm 11.0$ & $10.4 \pm 1.0$ & - \\
\hline$g$ & $1.32 \pm 0.31$ & $0.74 \pm 0.20$ & $12.0 \pm 2.2$ & $59.6 \pm 9.0$ & $1.00 \pm 0.16$ & $118.4 \pm 26.6$ & $23.0 \pm 5.7$ & - & $39.2 \pm 10.6$ \\
\hline \multicolumn{10}{|c|}{ S.glomeratum } \\
\hline$j$ & $0.54 \pm 0.11$ & $0.40 \pm 0.05$ & $5.0 \pm 0.6$ & $21.0 \pm 5.3$ & $0.54 \pm 0.10$ & $15.8 \pm 3.0$ & $9.3 \pm 2.4$ & $9.6 \pm 1.0$ & - \\
\hline im & $0.76 \pm 0.15$ & $0.67 \pm 0.11$ & $7.8 \pm 1.4$ & $41.6 \pm 10.0$ & $0.85 \pm 0.23$ & $30.6 \pm 3.7$ & $23.1 \pm 5.6$ & $11.4 \pm 0.7$ & - \\
\hline$v$ & $1.56 \pm 0.41$ & $0.80 \pm 0.22$ & $14.1 \pm 1.7$ & $66.1 \pm 8.1$ & $1.03 \pm 0.05$ & $99.0 \pm 30.2$ & $32.6 \pm 4.5$ & $12.2 \pm 0.3$ & - \\
\hline$g$ & $1.44 \pm 0.41$ & $0.72 \pm 0.11$ & $12.0 \pm 1.4$ & $59.0 \pm 11.0$ & $1.01 \pm 0.07$ & $98.0 \pm 18.1$ & $35.2 \pm 2.3$ & - & $30.0 \pm 4.2$ \\
\hline \multicolumn{10}{|c|}{ S. gramineum } \\
\hline$j$ & $0.53 \pm 0.14$ & $0.36 \pm 0.07$ & $6.0 \pm 1.0$ & $22.0 \pm 8.1$ & $0.25 \pm 0.03$ & $28.2 \pm 6.5$ & $11.8 \pm 3.0$ & $9.3 \pm 1.2$ & - \\
\hline im & $0.95 \pm 0.25$ & $0.60 \pm 0.14$ & $7.3 \pm 1.1$ & $87.2 \pm 51.6$ & $0.27 \pm 0.05$ & $53.7 \pm 11.6$ & $21.0 \pm 4.0$ & $10.1 \pm 1.0$ & - \\
\hline$v$ & $1.60 \pm 0.40$ & $0.77 \pm 0.20$ & $8.5 \pm 1.0$ & $121.5 \pm 39.3$ & $0.40 \pm 0.06$ & $87.6 \pm 26.2$ & $29.5 \pm 4.7$ & $10.0 \pm 1.0$ & - \\
\hline$g$ & $1.42 \pm 0.35$ & $0.62 \pm 0.08$ & $8.8 \pm 1.0$ & $145.0 \pm 22.0$ & $0.32 \pm 0.04$ & $87.3 \pm 20.2$ & $33.4 \pm 3.0$ & - & $253.7 \pm 29.1$ \\
\hline \multicolumn{10}{|c|}{ S. natans* } \\
\hline$j$ & $0.24 \pm 0.06$ & $0.17 \pm 0.04$ & $5.1 \pm 0.5$ & $9.0 \pm 7.8$ & $0.16 \pm 0.07$ & $4.1 \pm 1.0$ & $3.5 \pm 0.3$ & $9.1 \pm 0.3$ & - \\
\hline & $\underline{0.60 \pm 0.30}$ & $\underline{0.27 \pm 0.04}$ & $\underline{7.6 \pm 0.7}$ & $10.5 \pm 2.0$ & $\underline{0.30 \pm 0.05}$ & $\underline{10.7 \pm 5.3}$ & $\underline{7.5 \pm 1.2}$ & $\underline{8.7 \pm 1.2}$ & \\
\hline & $0.72 \pm 0.10$ & $0.28 \pm 0.04$ & $8.0 \pm 1.0$ & $32.1 \pm 3.3$ & $0.36 \pm 0.02$ & $8.0 \pm 1.3$ & $10.0 \pm 1.3$ & $11.5 \pm 1.3$ & - \\
\hline \multirow[b]{2}{*}{$v$} & $\underline{0.72 \pm 0.30}$ & $\underline{0.30 \pm 0.04}$ & $\underline{11.1 \pm 4.3}$ & $12.0 \pm 2.2$ & $\underline{0.31 \pm 0.06}$ & $\underline{23.7 \pm 9.6}$ & $16.0 \pm 4.7$ & $\underline{9.0 \pm 1.0}$ & \\
\hline & $0.86 \pm 0.40$ & $0.30 \pm 0.05$ & $10.7 \pm 4.5$ & $31.7 \pm 5.2$ & $\overline{0.40 \pm 0.04}$ & $\overline{23.3 \pm 1.6}$ & $\overline{11.6 \pm 3.2}$ & $\overline{10.5 \pm 1.3}$ & - \\
\hline \multirow[b]{2}{*}{$g$} & $1.17 \pm 0.25$ & $\underline{0.31 \pm 0.06}$ & $12.2 \pm 3.0$ & $13.6 \pm 1.5$ & $\underline{0.40 \pm 0.02}$ & $49.4 \pm 12.5$ & $\underline{21.5 \pm 4.6}$ & & $\underline{14.1 \pm 2.3}$ \\
\hline & $1.00 \pm 0.10$ & $0.30 \pm 0.04$ & $15.0 \pm 2.8$ & $30.3 \pm 1.3$ & $0.45 \pm 0.04$ & $43.8 \pm 3.0$ & $18.0 \pm 5.0$ & - & $35.6 \pm 5.1$ \\
\hline
\end{tabular}

Note: ontogenetic age state: $j$-juvenile, im-immature, $v$-virginile, $g$ - generative; ${ }^{*}$ - above the dash - emersed ecological form (habitually and morphologically similar to the terrestrial form, but grows in shallow-water areas), below the dash - submerged form with leaves floating on the water surface; "-“-parameter is absent. 


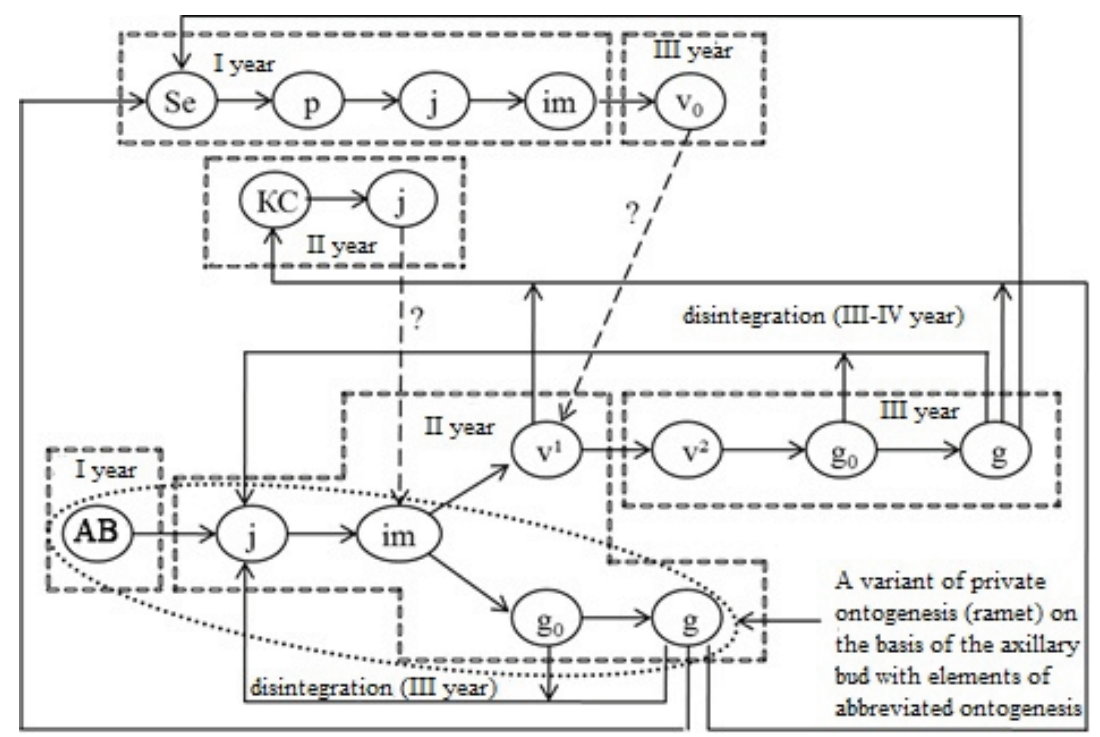

Fig. 7. Polyvariance of ontogenesis of model species of Sparganium: Se - seeds; $p$-seedling; $j$-juvenile age state; im -immature age state; $v_{0}$-young virginile age stae; $v_{l-2}$ - virginile age state; $g_{0}$ - cryptogenerative age state; $g$ - generative age state; TLS - axillary tuber-like structure;

$\mathrm{AB}$ - axillary bud; dash and dash line with question mark - presumed courses of ontogenesis; the remaining explanations are in the text

\section{Discussion}

Three main criteria for successful vital activity of an organism can be proposed - preservation of a species (survivability and fertility of individuals), enlarging of the distribution range and occupation by a plant of an ecological niche (Batygin, 1986). In the light of this statement, particularly about ontogenesis, we can outline one of the leading factors (multiplication of structural reserves) which have a direct effect on the vital strategy of a species.

It was found that seed reproduction of the Sparganium species we studied in the territory of European Russia is suppressed (Belyakov \& Lapirov, 2015a). The latter is conditioned by peculiarities of the structure of seeds' pericarps (Muenscher, 1936; Steinbauer \& Neal, 1950; Belyakov \& Lapirov, 2015a) and their slow and irregular germination (Martin \& Uhler, 1939 - as cited in Steinbauer \& Neal, 1950). Therefore, reports about discovery of large numbers of $S$. emersum seedlings in water bodies of Moscow Oblast in early June (Boiko \& Alekseev, 1990) are doubtful. We have found no seedlings of this species. Once we found only singular juvenile plants of $S$. gramineum, which grew in sandy shallow-water areas not occupied by other plants (Sig Lake Tver Oblast, Ostashkovsky district and the Ruimnikovo Lake Yaroslavl Oblast, Rostov district).

Experiments on germination the seeds of the species of Sparganium we studied demonstrate that it is difficult for them to germinate (Lapirov \& Belyakov, 2015a). Taking into account that the depth of condition of rest is assessed according to the ability of seed to germinate (Come, 1970 cited as in Levak \& Rudnickiy, 1982), we consider that seeds of Sparganium have a combined type of state of rest $\left(\mathrm{A}_{\mathrm{f}}-\mathrm{BV}-\mathrm{V}_{1-3},-\right.$ terminology of Nikolaeva et al. (1999)). The latter is related to water-resistance of the coats of the seeds, the undeveloped state of the embryo and its physiological condition (impact of physiological mechanism of inhibition of germination - PMI). The most effective way to overcome the dormant state is cold humid stratification (Nikolaeva et al., 1999). In natural conditions, slow course of germination of the seeds is for many species (especially of the temperate zone) an important adaptive ability to the conditions of variable climate, and functions as a necessary tool for their survival (Crocker \& Barton, 1955; Poptsov et al., 1981), and contributes to the formation of the soil seed bank. The process of germination inhibition can be related to the property of bur-reed seeds to remain intact on the water surface. We should note that van den Broek et al. (2005) have earlier noted possible co-evolution between the ability of seeds and fruits to remain on the water surface and inhibition of their germination.

During the monitoring of ontogenesis of model species of bur-reed, we determined that the representatives of Xanthosparganium subgenus are characteristic of combining incomplete (from generative diaspore and axillary TLS) and specific (from axillary buds of dicyclic and tricyclic vegetative-generative shoots) types of ontogenesis. On the basis of the latter, a variant of shortened ontogenesis is possible. Ontogenesis of burreeds corresponds to D-type (according to Zhukova (1995)). We should note that combining incomplete and shortened ontogenesis is a feature characteristic of many aquatic plants (Savinykh, 2003). Therefore in vegetative-mobile plants (to which the group of species we studied belongs), monitoring complete ontogenesis in natural conditions is practically impossible due to active vegetative reproduction and, often inhibited generative reproduction.

Earlier, while studying a number of species of bur-reed, we demonstrated that over one vegetative period, on the base of tricyclic vegetativegenerative shoots of Sparganium, the sympodium forms, which consists of dicyclic vegetative-generative anchor shoots, di- and monocyclic vegetative shoots. At the same time, each shoot which is unit of count is in a certain way an autonomous formation. At the same time, autonomisation of the shoots reduces internal relations in the shoot system of a plant (Savinykh \& Cheryomushkina, 2015), on one hand, and continues to contribute to increase in total area of assimilating surface of the system of anchor shoots on the other hand.

Bur-reed's anchor shoots develop in a sylleptic way during iterative branching out of axillary buds of rosette shoots of previous order. We should note that we consider uniform initiation of buds and formation of shoots throughout the vegetative season (on the basis of tricyclic monocarpic shoot) as heterochrony, probably formed as a result of natural selection (Savinykh et al., 2015). Along with active growth of population in horizontal direction (due to di- and monocarpic shoots), bur-reeds, similarly to a number of other shoreline-aquatic plants of seasonal climate (for example Glyceria maxima (Hartm.) Holmb., Phragmites australis (Cav.) Trin. ex Steud.), can colonise and maintain themselves different sites which they have earlier settled in multiple times (Savinykh et al., 2015; Belyakov \& Lapirov, 2018).

The biological aspect of adaptive significance of plants in ontogenesis is also revealed by morphological fragmentation (Savinykh, 2003). In Sparganium it is specialized (by presence/absence of specialized structures of reproduction), complete (by complete division of mother plant into daughter plants) and normal (by time of formation in ontogenesis). Presence of processes of fragmentation contributes to active vegetative reproduction due to the large number of young ramets. Thus bur-reeds, similarly to other vegetative-mobile plants, become practically immortal. Similar opinion was expressed by Smirnova (1967), who studied individual development of Carex pilosa Scop. and Aegopodium podagraria L. Increase in the tempo of life cycle of bur-reed (during development mostly according to incomplete type of ontogenesis) (Zhukova, 1995; Savinykh et al., 2015) occurs due to avoidance of the 
virginile ontogenetic age state (shortened ontogenesis) during formation of dicyclic vegetative-generative semi-rosette shoots. We assess such a peculiarity as dynamic polyvariance of the individual development of Sparganium. The combination of incomplete type of ontogenesis with shortened type is related to omission of the phase of post-generative period. As a result of this, we can observe a tendency common for many aquatic and shoreline-aquatic plants - "tendency towards reduction of life span of ramets during prolongation of ontogenesis of the entire plant with preservation of its polycarpy" (Savinykh et al., 2015, p. 680); and, at the same time, increase in total seed productivity of the species and assimilating surface. The latter leads to enlargement of adaptation abilities of this species and strengthening of stability of its populations.

Also the adaptive role of Sparganium, related to the formation of shortened shoots (stolons, often ramified) from the axillary buds of a flower-bearing stem, which have tuber-like structures at the end (specialized diasporas) can be conditioned by compensation of time used for reproductive breeding. We earlier observed such structures in $S$. gramineum, $S$. natans and $S . \times$ longifolium.

\section{Conclusions}

The representatives of the genus Sparganium are characterized by combining incomplete and specific types of ontogenesis. At the same time, the modal course of ontogenesis in natural conditions corresponds to D-type. We consider increase in tempi of the development of dicyclic vegetative-generative middle-rosette shoots with avoidance of virginile ontogenetic age state (shortened ontogenesis) as a dynamic polyvariance of ontogenesis, while uniform initiation of buds and formation of shoots throughout the vegetative period - as heterochrony. These peculiarities provide various courses of ontogenesis, and as a result - enlargement of the ecological niche of the species.

Dynamic and temporal peculiarities of formation of ramets of Sparganium are conditioned by peculiarities of rhythm of the development formed in conditions of seasonal climate. The latter is reflected also in the enlargement of range of cyclicity of different types of shoots. Also, this peculiarity has no significant effect on slowing or accelerating the processes of the development of a group and division of mother plants into daughter plants within it. These peculiarities enlarge the adaptive abilities of a population, determine its constant heterogeneity and stability (Zhukova, 2001) in changing environmental conditions.

The study was performed within the scope of the scientific project RFBR No 1834-00257 mol_a "Molecular phylogeny, adaptive potential and features of the morphological evolution of some vascular plants in the development of the aquatic environment".

\section{References}

Akhmedov, A. K., Shomurodov, H. F., \& Nomozova, Z. B. (2016). The ontogenesis and ontogenetic structure of Lagochilus proskorjakovii Ikram (Lamiaceae) coenopopulations in Nuratau Mountain Range (Uzbekistan). American Journal of Plant Sciences, 7, 928-936.

Anisimova, G. M. (1990). Semejstvo Typhaceae [Family Typhaceae]. Sravnitelnaya ehmbriologiya cvetkovyh rastenij. Odnodolnye. Butomaceae - Lemnaceae [Comparative embryology of flowering plants. Monocotyledons. Butomaceae Lemnaceae]. Nauka, Leningrad. Pp. 271-274 (in Russian).

Batygin, N. F. (1986). Ontogenez vysshih rastenij [Ontogenesis of higher plants]. Agropromizdat, Moscow (in Russian).

Belyakov, E. A., \& Lapirov, A. G. (2015a). Fruit germination of some representatives of the family Sparganiaceae Rudolphi under laboratory conditions. Inland Water Biology, 8(1), 33-37.

Belyakov, E. A., \& Lapirov, A. G. (2015b). Modular and structural-functional organization of g. Sparganium L. species in different ecological conditions. Contemporary Problems of Ecology, 8(5), 647-659.

Belyakov, E. A., \& Lapirov, A. G. (2018). Morphological and ecological cenotic features of the relict species Sparganium gramineum Georgi (Typhaceae) in waterbodies of European Russia. Inland Water Biology, 11(4), 417-424.

Belyakov, E. A., \& Philippov, D. A. (2018). The effect of changes in environmental conditions on the morphology of Sparganium natans L. (Typhaceae) in the taiga zone of European Russia. Ecosystem Transformation, 1(1), 29-41.
Belyakov, E. A., Lapirov, A. G., \& Lebedeva, O. A. (2017). Ecology of seed germination and features of ontogeny of floating mat-forming hygrogelophyte Calla palustris (Araceae) under laboratory conditions. Biosystems Diversity, 25(4), 282-288 (in Russian).

Boiko, G. A., \& Alekseev, Y. E. (1990). Ezhegolovnik vsplyvshij [Sparganium emersum]. Biologicheskaya flora Moskovskoi oblasti, 8, 63-77 (in Russian).

Borovik, T. S., \& Revushkin, A. S. (2018). Ontogenesis and age structure characteristics of Dasystephana macrophylla (Pallas) Zuev populations in the Altai Mountains. Tomsk State University Journal of Biology, 41, 42-52 (in Russian).

Cook, C. D. K. (1962). Sparganium erectum L. (S. ramosum Hudson, nom. illeg.). Journal of Ecology, 50(1), 247-255.

Crocker, W., \& Barton, L. V. (1955). Fiziologiya semyan [Physiology of seeds]. Izdatelstvo Inostrannoy Literatury, Moscow (in Russian).

Evstigneev, O. I., \& Korotkov, V. N. (2016). Ontogenetic stages of trees: An overview. Russian Journal of Ecosystem Ecology, 2(2), 1-31 (in Russian).

Grudzinskaya, I. A. (1960). Letnee pobegoobrazovanie u drevesnyh rastenij i ego klassifikaciya [Summer shoot formation in woody plants and its classification]. Botanicheskii Zhurnal, 45(7), 968-978 (in Russian).

Hohryakov, A. P. (1975). Zakonomernosti evolyutsii rastenij [Consistent patterns of plant evolution]. Nauka, Novosibirsk (in Russian).

Ishii, T., Nakayama, Y., \& Yamaguchi, H. (2005). A note on phenology and seed germination behavior in two natural populations of the endangered aquatic macrophytes Sparganium erectum var. erectum and Sparganium erectum var. macrocarpum. Journal of Weed Science and Technology, 50(2), 82-90.

Khrolenko, Y. A., Burundukova, O. L., Bezdeleva, T. A., Muzarok, T. I., \& Zhuravlev, Y. N. (2007). Age stages in the ontogeny of cultivated Panax ginseng C. A. Mey. Biological Bulletin, 34(2), 120-125.

Kim, S. H., Nam, J. M., \& Kim, J. G. (2017). Establishment strategy of a rare wetland species Sparganium erectum in Korea. Journal of Ecology and Environment, 41, 27.

Kirichok, E. I. (2016). Ontogenesis of Grecian juniper (Juniperus excelsa M. Bieb) in sparse forests of the Black Sea Coast of the Crimea and the Caucasus. Russian Journal of Ecosystem Ecology, 1(3), 1-22 (in Russian).

Komarov, A. S., Palenova, M. M., \& Smirnova, O. V. (2003). The concept of discrete description of plant ontogenesis and cellular automata models of plant populations. Ecological Modelling, 170, 427-439.

Kubentaev, S. A., \& Danilova, A. N. (2016). Evaluation of ecological and biological characteristics of Rhaponticum carthamoides (Willd.) Iljin and its resource indicators on the Ridge of Ivanovo (Eastern Kazakhstan). Tomsk State University Journal of Biology, 37, 31-46 (in Russian).

Lapirov, A. G. (2014). Peculiarities of the ontogenesis of Alisma plantago-aquatica L. (Alismataceae). Tomsk State University Journal of Biology, 1(25), 66-89 (in Russian).

Lapirov, A. G. (2015). Ontogeny of terrestrial and submerged forms Alisma gramineum Lej. (Alismataceae). Transactions of Papanin Institute for Biology of Inland Waters RAS, 71, 78-91 (in Russian).

Lapirov, A. G., Belyakov, E. A., \& Lebedeva, O. A. (2018). Ontogeny of Lobelia dortmanna genets in lake ecosystems. Regulatory Mechanisms in Biosystems, 9(2), 237-243 (in Russian).

Levak, S., \& Rudnickiy, P. M. (1982). Posleuborochnoe dozrevanie semyan, nuzhdayushchihsya $\mathrm{V}$ vozdeystvii nizkih temperatur [Postharvest ripening of seeds in need of exposure to low temperatures]. Fiziologiya i biohimiya pokoya i prorastaniya semyan [Physiology and biochemistry of rest and germination of seeds]. Kolos, Moscow. Pp. 226-251 (in Russian).

Logofet, D. O., Ulanova, N. G., \& Belova, I. N. (2016). Polyvariant ontogeny in woodreeds: Novel models and new discoveries. Biology Bulletin Reviews, 6(5), 365-385.

Martínková, J., \& Klimešová, J. (2017). Position of tillers in a clone determines their ontogeny: Example of the clonal grass Phalaris arundinacea. Folia Geobotanica, 52 (3-4), 317-325.

Nikolaeva, M. G., Lyanguzova, I. V., \& Pozdova, L. M. (1999). Biologiya semyan [Biology of seeds]. NII Khimii Sankt-Peterburg Gosudarstvennyj Universitet, St. Petersburg.

Pollux, B. J. A. (2011). The experimental study of seed dispersal by fish (ichthyochory). Freshwater Biology, 56(2), 197-212.

Pollux, B. J. A., De Jong, M., Steegh, A., Ouborg, N. J., Van Groenendael, J. M., \& Klaassen, M. (2006). The effect of seed morphology on the potential dispersal of aquatic macrophytes by the common carp (Cyprinus carpio). Freshwater Biology, 51(11), 2063-2071.

Pollux, B. J. A., Ouborg, N. J., van Groenendael, J. M., \& Klaassen, M. (2007). Consequences of intraspecific seed-size variation in Sparganium emersum for dispersal by fish. Functional Ecology, 21(6), 1084-1091.

Poptsov, A. V., Nekrasov, V. I., \& Ivanova, I.A. (1981). Ocherki po semenovedeniyu [Essays on seed science]. Nauka, Moscow (in Russian).

Rabotnov, T. A. (1950). Zhiznennyj cikl mnogoletnih travyanistyh rastenii v lugovyh cenozah [Life-cycle of perennial herbaceous plants in meadow coenoses]. Trudy Botanicheskogo Instituta Akademii Nauk SSSR. Seriya 3. Geobota- 
nica [Bulletin of the Academy of Sciences of the USSR], 3(6), 77-204 (in Russian).

Sakhonenko, A. N., \& Matyukhin, D. L. (2018). Ontogeny stages of seed propagation of individual species of Viburnum opulus L.). Izvestia of Timiryazev Academy, 4, 99-110 (in Russian).

Savinykh, N. P. (2003). Ontogenez i ego osobennosti u vodnyh rastenij [Ontogenesis and its features in aquatic plants]. Gidrobotanika: metodologiya i metody [Hydrobotanics: methodology and methods]. Rybinskiy Dom Pechati, Rybinsk, 98-105 (in Russian).

Savinykh, N. P., \& Cheryomushkina, V. A. (2015). Biomorphology: Current status and prospects, 8(5), 541-549.

Savinykh, N. P., Shabalkina, S. V., \& Lelekova, E. V. (2015). Biomorphological adaptations of helophytes. Contemporary Problems of Ecology, 8(5), 550-559.

Serebrjakov, I. G. (1952). Morfologiya vegetativnyh organov vysshih rastenij [Morphology of vegetative organs of higher plants]. Sovetskaya Nauka, Moscow (in Russian).

Silayeva, Z. G. (2014). Polyvariantness of ontogenesis of Polypodium vulgare L. sporophytes. Modem Phytomorphology, 6, 235-238 (in Russian).

Smirnova, O. V. (1967). Ontogenez i vozrastnye gruppy osoki volosistoj (Carex pilosa Scop.) i snyti obyknovennoj (Aegopodium podagraria L.) [Ontogeny and age groups of Sedge (Carex pilosa) and Goutweed (Aegopodium podagraria)]. Ontogenez i vozrastnoj sostav populyacij cvetkovyh rastenij [Ontogenesis and age composition of populations of flowering plants], Nauka, Moscow. Pp. 100-113 (in Russian).

Steinbauer, G. P., \& Neal, O. (1950). Dormancy and germination of seeds of the bur reeds, Sparganium spp. Papers of the Michigan Academy of Science, Arts and Letters, 34(1), 33-38.

Sulman, J. D., Drew, B. T., Drummond, C., Hayasaka, E., \& Sytsma, K. J. (2013). Systematics, biogeography, and character evolution of Sparganium (Typhaceae): Diversification of a widespread aquatic lineage. American Journal Botany, 100(10), 2023-2039.

Szmeja, J. (1987a). The seasonal development of Lobelia dortmanna L. and annual balance of its population size in an oligotrophic lake. Aquatic Botany, 28(1), 15-24.

Szmeja, J. (1987b). The ecology of Lobelia dortmanna L. II. Population structure and dynamics within a constant depth interval in oligotrophic lakes. Ekologia Polska, 35, 523-544.
Szmeja, J. (1994). Effect of disturbances and interspecific competition in isoetid populations. Aquatic Botany, 48, 225-238.

Talovskaya, E. B. (2017). Polyvariance of Thymus mugodzharicus (Lamiaceae) ontogeny of the cushion-like life form. Tomsk State University Journal of Biology, 40, 88-101 (in Russian).

Teteryuk, L. V., Valuiskikh, O. E., \& Savinykh, N. P. (2013). Biomorphology and ontogeny of Gymnadenia conopsea (L.) R. Br. (Orchidaceae) in marginal populations on limestones in the northeast of European Russia. Russian Journal of Ecology, 44(4), 254-262.

Tillich, H.-J. (2007). Seedling diversity and the homologies of seedling organs in the order Poales (Monocotyledons). Annals of Botany, 100(7), 1413-1429.

Uranov, A. A. (1975). Vozrastnoj spektr fitopopulyatsij kak funktsiya vremeni i energeticheskih volnovyh protsessov [Age range of phytopopulations as a function of time and energetical wave processes]. Biologicheskie Nauki [Biological Science], 2, 7-35 (in Russian).

van den Broek, T., van Diggelen, R., \& Bobbink, R. (2005). Variation in seed buoyancy of species in wetland ecosystems with different flooding dynamics. Journal of Vegetation Science, 16, 579-586.

Vasilchenko, I. T. (1936). O znachenii morfologii prorastaniya dlya sistematiki rastenij $\mathrm{i}$ istorii ih proishozhdeniya [On the importance of germination for plant systematics and history of their origin]. Memior of BIN RA USSR. Ser. 1. Flora and higher plant systematics, 3, 7-66 (in Russian).

Zhou, B., Tu, T., Kong, F., Wen, J., \& Xu, X. (2018). Revised phylogeny and historical biogeography of the cosmopolitan aquatic plant genus Typha (Typhaceae). Scientific Reports, 8(1), 8813.

Zhukova, L. A. (1995). Populyacionnaya zhizn lugovyh rastenij [Population life of meadow plants]. Lanar, Joshkar-Ola (in Russian).

Zhukova, L. A. (2001). Diversity of ontogenetic pathways in plant populations. Russian Journal of Ecology, 32(3), 151-158.

Zhukova, L. A., \& Glotov, N. V. (2001). Morphological polyvariance of ontogeny in natural plant populations. Russian Journal of Developmental Biology, 32(6), 381-387.

Zhukova, L. A., Kozyreva, S. V., Zubkova, E. V., Osmanova, G. O., \& Vedernikova, O. P. (2016). Ontogenetic museum of plants of Mari State University. Russian Journal of Ecosystem Ecology, 1(4), 1-14 (in Russian).

Zubkova, I. G., \& Shabes, L. K. (1983). Anatomical structure of the pericarp of Sparganium species (Sparganiaceae). Botanicheskii Zhurnal, 68(3), 381-385 (in Russian). 